\title{
Medical Encounter Characteristics of HIV Seroconverters in the US Army and Air Force, 2000-2004
}

\author{
Shilpa Hakre \\ Henry M. Jackson Foundation for the Advancement of Military Medicine \\ David Brett-Major \\ University of Nebraska Medical Center, david.brettmajor@unmc.edu \\ Darrell E. Singer \\ Walter Reed Army Institute of Research \\ Robert J. O'Connell \\ Walter Reed Army Institute of Research \\ Warren B. Sateren \\ Walter Reed Army Institute of Research
}

See next page for additional authors

Tell us how you used this information in this short survey.

Follow this and additional works at: https://digitalcommons.unmc.edu/coph_epidem_articles

Part of the Epidemiology Commons

\section{Recommended Citation}

Hakre, Shilpa; Brett-Major, David; Singer, Darrell E.; O'Connell, Robert J.; Sateren, Warren B.; Sanchez, Jose L.; Agan, Brian K.; Michael, Nelson L.; and Scott, Paul T., "Medical Encounter Characteristics of HIV Seroconverters in the US Army and Air Force, 2000-2004" (2011). Journal Articles: Epidemiology. 25. https://digitalcommons.unmc.edu/coph_epidem_articles/25 


\section{Authors}

Shilpa Hakre, David Brett-Major, Darrell E. Singer, Robert J. O'Connell, Warren B. Sateren, Jose L. Sanchez, Brian K. Agan, Nelson L. Michael, and Paul T. Scott 


\title{
Medical Encounter Characteristics of HIV Seroconverters in the US Army and Air Force, 2000-2004
}

\author{
Shilpa Hakre, DrPH, MPH, * David M. Brett-Major, MD, MPH, $+\neq$ Darrell E. Singer, MD, MPH, $\S$ \\ Robert J. O'Connell, MD, \& Warren B. Sateren, MPH, \& Jose L. Sanchez, MD, MPH," \\ Brian K. Agan, MD, \ Nelson L. Michael, MD, PhD, $\S$ and Paul T. Scott, MD, MPH§
}

\begin{abstract}
Background and Methods: Active duty US Army and Air Force military personnel undergo mandatory biennial HIV antibody screening. We compared pre- and post-HIV seroconversion health status by conducting a case-control study, which evaluated all medical encounters and sociodemographic factors among incident HIV seroconverters and HIV-negative controls from June 2000 through February 2004.
\end{abstract}

Results: A total of 274 HIV seroconverters and 6205 HIV-negative personnel were included. In multivariate analysis restricted to male personnel $($ cases $=261$, controls $=5801)$, single marital status (adjusted odds ratio $[\mathrm{AOR}]=14.37$ ), clinical indicators or symptoms within four years of HIV diagnosis ( $\mathrm{AOR}=6.22)$, black race $(\mathrm{AOR}=5.88)$, nonindicator clinical syndromes within 2 years of HIV diagnosis (AOR = 3.31 ), any mental disorder within 4 years of HIV diagnosis $(\mathrm{AOR}=$ 3.04), increasing service-connected time ( $\mathrm{AOR}=1.69)$, and older age $(\mathrm{AOR}=1.12)$ were associated with HIV diagnosis among males. A prior history of a sexually transmitted infection (STI) was associated with post-HIV seroconversion STI $\left(\mathrm{OR}_{\mathrm{M}-\mathrm{H}}=4.10\right)$. Similarly, a prior history of mental disorder was associated with post-HIV seroconversion mental disorder $\left(\mathrm{OR}_{\mathrm{M}-\mathrm{H}}=4.98\right)$. Forty-seven $(18 \%)$ male cases were hospitalized at least once after HIV diagnosis; infectious diseases, and mental disorders made up $53 \%$ of initial admissions.

Received for publication October 21, 2010; accepted December 8, 2010. From the *Department of Epidemiology and Threat Assessment, United States Military HIV Research Program, Henry M. Jackson Foundation for the Advancement of Military Medicine, Rockville, MD; †U.S. Military Tropical Medicine, Navy Medicine Manpower, Personnel, Training \& Education Command, Bethesda, MD; $\ddagger$ Department of Preventive Medicine and Biometrics, Uniformed Services University of the Health Sciences, Bethesda, MD; §Division of Retrovirology, Walter Reed Army Institute of Research, Rockville, MD; "The Department of Defense Global Emerging Infections Surveillance and Response System (DoD-GEIS), Armed Forces Health Surveillance Center, Silver Spring, MD; and IInfectious Disease Clinical Research Program, Uniformed Services University, Bethesda, MD.

This work was supported by funds from the Military Infectious Disease Research Program (Proposal 1A0001_06_WR_OC) and approved by the Walter Reed Army Institute of Research Institutional Review Board (\#1109).

The views expressed are those of the authors and should not be construed to represent the positions of the US Department of Defense, the US Government, or any of its agencies.

Correspondence to: Dr. Shilpa Hakre, Epidemiology and Threat Assessment, US Military HIV Research Program, 1 Taft Ct. Suite 250, Rockville, MD 20850 (e-mail: shakre@hivresearch.org).

Supplemental digital content is available for this article. Direct URL citations appear in the printed text and are provided in the HTML and PDF versions of this article on the journal's web site (www.jaids.com).

Copyright (c) 2011 by Lippincott Williams \& Wilkins
Conclusions: HIV seroconversion was associated with increased health care-seeking behavior, STIs, and mental disorders, some of which may be amenable to screening. The higher STI rate after HIV diagnosis may partially be a consequence of monitoring, but secondary transmission of STI and possibly HIV require further definition and subsequent tailored preventive interventions.

Key Words: medical encounters HIV Army Air Force

(J Acquir Immune Defic Syndr 2011;56:372-380)

\section{INTRODUCTION}

Approximately, one-third of the US population with HIV infection is unaware of their serostatus. ${ }^{1}$ Undiagnosed HIV prevalence differs by racial makeup and behavioral risks. ${ }^{1}$ Early diagnosis of HIV provides opportunities for interrupting transmission of the virus and improving disease progression through earlier access to specialized medical care. Serum viral load levels are associated with HIV transmission especially during the early and late stages of HIV disease. ${ }^{2,3}$ In the era of antiretroviral therapy, treatment leads to reduced viral loads and transmission with improvement in health outcomes. ${ }^{3}$ In populations with access to health care, delayed HIV testing has been associated with late presentation and poor outcomes. ${ }^{4-6}$ Although recognition of acute HIV infection in presenting patients affords a public health opportunity for decreasing HIV transmission, attention to clinical indicators alone has not prompted targeted testing in clinical settings. ${ }^{7,8}$ Identification of additional factors such as recent sexually transmitted infection (STI) may aid in targeted testing. ${ }^{9}$

The US armed forces began mandatory periodic screening for HIV antibody in $1985 .{ }^{10}$ Screening was initiated for maintaining the health, well-being, and military readiness of personnel, ensuring a safe blood supply in combat situations of "buddy transfusions," and preventing adverse events from live virus vaccinations among HIV-infected personnel. ${ }^{11}$ The interval in screening varied by Service from 1-5 years. Beginning in 2004, the screening interval was standardized across Services to 2 years as infected people rarely progressed to AIDS within 2 years. ${ }^{12}$ Although the US military's HIV incidence and prevalence average $0.02 \%$, significantly lower than in the US civilian population, ${ }^{13}$ HIV incidence has been increasing among military personnel from 2000 to $2008 .^{14,15}$ We conducted our study to identify factors which may promote earlier diagnosis of HIV, augmenting current screening strategies. We were interested in studying if medical conditions 
and visits before HIV seroconversion differed among HIVinfected compared with uninfected Soldiers and Airmen and to see if these associations persisted after HIV diagnosis. Additionally, we describe sociodemographic differences between HIV seroconverters and controls.

\section{METHODS}

\section{Study Population}

The data reported here were collected for a seroepidemiologic case-control study among active duty and reserve US Army and Air Force personnel, for which the methods have been described. ${ }^{16,17}$ Using HIV test dates for selection, the broader study randomly sampled 20 controls to a case and frequency matched by gender. The control to case ratio was driven by reported demographic differences among HIVinfected and HIV-uninfected military personnel, and to ensure that demographics of the controls were representative of the military population. Because females represent a small proportion of US military personnel and HIV seroconverters, frequency matching assisted similar proportions as cases. ${ }^{18,19}$

We restricted our study to active duty personnel. Active duty personnel can access care in the military health system throughout their service, whereas reservists have limited access when not activated. Cases were active duty US Army and Air Force personnel newly diagnosed with HIV from June 1, 2000, through February 29, 2004, with evidence of at least 1 medical encounter in the 4 years preceding diagnosis. Controls were active duty Army and Air Force personnel with a HIV-negative test in a 30-day interval of a case's first-positive HIV test with at least 1 medical encounter in the preceding 4 years. Index dates for cases were the date of blood draw of the first HIV confirmed positive serological test result and for controls the date of the HIV-negative serological test within the case date interval.

\section{Data Collection}

Longitudinal sociodemographic information, outpatient and inpatient medical encounters, duty assignment, and deployment histories were obtained from the Defense Medical Surveillance System. ${ }^{20}$ During the study period, active duty Soldiers were routinely screened for HIV every 2 years although Airmen were screened every 3-5 years. ${ }^{21}$ For HIVinfected military personnel with a last negative HIV test within 1 year of the first-positive HIV test result, the dates of lastnegative HIV tests were obtained. Medical encounter records (up to 4 years preceding and after the index date) included visit dates and up to 8 ( 4 for outpatient, 8 for inpatient) International Classification of Diseases, Ninth Revision, Clinical Modification (ICD-9-CM) diagnostic codes. Duty assignment (up to 5 years before the index date) and deployment roster records (up to 4 years before and after the index date) provided start and end dates, and locations of assignments and military deployments.

\section{Data Analysis}

Characteristics considered for analysis were disease groups, medical diagnoses, medical diagnosis clusters, medical encounter frequency, reasons for first postindex hospitalization, demographic characteristics at index date, frequencies of preindex permanent changes of station (PCS's) and deployments, deployment in the year before the index date, and period of observation in years before (follow-back) and after (follow-up) the index date. Follow-back time served as a surrogate for length of service connection. Medical visits were summarized before and after index dates, by visit type (inpatient or outpatient) and compared between cases and controls. Multiple records on the same day and health care setting were considered duplicate records and deleted for medical visit enumeration.

Disease groups were compared between cases and controls to identify those associated with HIV infection. Incident ICD-9-CM codes in any position on medical encounter records before the index date were categorized into 19 standard groups to include as follows: infectious and parasitic diseases; mental disorders; digestive system; blood and blood-forming organs; respiratory system; musculoskeletal and connective tissue system; endocrine, nutritional and metabolic diseases, and immunity disorders; genitourinary systems; complications of pregnancy, childbirth, and the puerperium; injury and poisoning; neoplasms; skin and subcutaneous tissue; symptoms, signs, and ill-defined conditions; circulatory system; and supplementary classification of factors influencing health status and contact with health services ( $\mathrm{V}$ codes). ${ }^{22}$ Additionally, a literature search identified reported medical diagnoses and symptoms associated with primary HIV infection to include fever, fatigue, rash, headache, lymphadenopathy, arthralgias (myalgia, joint pain), pharyngitis (sore throat), nausea, vomiting, diarrhea, night sweats, neck stiffness, photophobia, weight loss (anorexia), loss of appetite, Bell's palsy, malaise, mucosal ulcers (oral or genital), leucopenia, thrombocytopenia, and elevated hepatic enzyme levels. ${ }^{23-33}$ Other reported risk conditions for HIV infection include STIs, infections (tuberculosis, candidiasis, Pneumocystis jirovecii pneumonia, varicella zoster virus), skin conditions (psoriasis, seborrheic dermatitis), and history of psychiatric hospitalization, alcohol dependence, homelessness, or cocaine use.

Incident ICD-9-CM codes among cases within statistically significant disease groups were selected for 2 periods, within 2 years and up to 4 years before HIV diagnosis, and subgrouped into reported HIV-associated medical diagnoses and other data-driven subgroups of interest: 9 STIs, 16 clinical indicators or symptoms for HIV infection, 4 mental disorders, and 5 potential clinical syndromes suggestive of primary HIV infection (see Appendix 1, Supplemental Digital Content 1, http://links.lww.com/QAI/A129). Medical diagnoses were collapsed into medical diagnosis clusters (MDC) and the effect of MDC on HIV status was evaluated for the 2 periods. For 10 HIV-infected cases with an inpatient or outpatient diagnosis of HIV ('042' ICD-9-CM or HIV disease) before the index HIV test date, the serological index date and analyses were adjusted to the earliest date of the ' 042 ' medical encounter.

Incident ICD-9-CM codes, in any position on medical encounter records, after index dates were subgrouped into medical diagnoses evaluated preindex date and compared for male military personnel only and their controls. Additionally, postindex diagnoses were compared between cases and controls by stratifying for history of preindex MDC. The primary diagnosis for first hospitalizations after HIV diagnosis was compared among hospitalized and nonhospitalized cases. The 
ICD-9-CM code in the first position on an inpatient record was considered the primary diagnosis unless the code indicated HIV infection (042, V08, 647.8, 795.71, or 795.79) whereby the second or third position provided primary diagnosis.

Bivariate analysis using Pearson $\chi^{2}$, Student $t$ test, and Wilcoxon rank sum test compared characteristics between cases and controls. The effect of a characteristic on HIV infection status was measured with an odds ratio. Two-sided confidence limits (CLs) for odds ratios and 2 -sided $P$ values for all analyses were assessed at a 95\% significance level. MDC associations with HIV infection were assessed adjusting for age, race, and service-connected time with logistic regression. Multivariate logistic regression analysis identified characteristics most significantly associated with HIV infection using a stepwise method of selecting characteristics. All characteristics significantly associated with HIV infection at $P<0.25$ in bivariate analysis were considered in multivariate models. In multivariate models, age, serviceconnected time, PCSs, deployments, deployment duration, and medical encounter frequency were evaluated as continuous variables, whereas branch of Service, race, marital status, and presence of medical diagnoses were evaluated as categorical variables. Race was collapsed into 2 categories (black and nonblack) based on contiguous levels having similar odds ratios. The Hosmer-Lemeshow test assessed the goodness of fit of the final model. All analysis was conducted using Statistical Analysis Software (SAS) version 9.1 (Cary, NC).

\section{RESULTS}

\section{Study Population}

Of 7027 active duty military personnel eligible for the study, 30 HIV-infected and 518 uninfected personnel were excluded. The 30 excluded individuals were in the Army, mostly male (97\%), and older (mean, 43.6 years, $P<0.0001$ ) than those included. HIV-infected cases and uninfected controls differed in demographic characteristics by Service $(P<0.05)$; Air Force cases were younger (mean years, 30.0; Army, 32.1), male (100\%; Army, 93\%), and single (72\%; Army, 48\%); Air Force controls were older (mean years, 28.6; Army, 27.5) and more frequently white (77\%; Army, 66\%) and less frequently single (61\%; Army, 54\%).

Of 274 HIV-infected cases in the study, most were male (95\%). Among men, most were aged $25-34$ years (45\%), single $(61 \%)$, of black race $(57 \%)$, and had earned a high school diploma or less at time of HIV diagnosis (67\%) (Table 1). Among male military personnel, age greater than 24 years (odds ratios $[\mathrm{ORs}]=1.68-1.81)$, single marital status $(\mathrm{OR}=2.37)$, black race $(\mathrm{OR}=5.76)$, and senior enlisted pay grade $(\mathrm{OR}=$ 1.46 for pay grades E05 to E09) conferred higher odds of HIV infection (Table 1). Three or more PCS's had slightly greater odds of HIV infection compared with those with 2 or fewer PCS's $(\mathrm{OR}=1.31$, Table 2). Being deployed for 5 months or longer $(\mathrm{OR}=0.57)$ was negatively associated with HIV infection compared with nondeployers (Table 2).

TABLE 1. Sociodemographic Characteristics of HIV Seroconverters and HIV-Uninfected Active Duty Army and Air Force Male Military Personnel, 2000-2004*

\begin{tabular}{|c|c|c|c|c|c|}
\hline & Case $(n=261)$ & Control $(\mathrm{n}=\mathbf{5 8 0 1})$ & Unadjusted Odds Ratio & $95 \% \mathrm{CL}$ & $\boldsymbol{P}$ \\
\hline \multicolumn{6}{|l|}{ Service } \\
\hline Army & $154(59)$ & $3662(63)$ & 0.84 & $(0.65$ to 1.08$)$ & 0.18 \\
\hline Air force & $107(41)$ & $2139(37)$ & Referent & - & - \\
\hline \multicolumn{6}{|l|}{ Grade } \\
\hline E00-E04 & $102(39)$ & $2519(43)$ & 1.12 & $(0.75$ to 1.66$)$ & 0.59 \\
\hline E05-E09 & $126(48)$ & $2372(41)$ & 1.46 & (0.99 to 2.16$)$ & 0.06 \\
\hline Officer & $33(13)$ & $910(16)$ & Referent & - & - \\
\hline \multicolumn{6}{|l|}{ Race } \\
\hline Black & $150(57)$ & $1145(20)$ & 5.76 & (4.40 to 7.53$)$ & $<0.0001$ \\
\hline Other & $15(6)$ & $521(9)$ & 1.27 & $(0.73$ to 2.20$)$ & 0.40 \\
\hline White & $91(35)$ & $4000(69)$ & Referent & - & - \\
\hline \multicolumn{6}{|l|}{ Age } \\
\hline Mean, median (minimum to maximum) & $30.1,29.0(19-52)$ & $28.5,27.0(17-63)$ & - & - & 0.001 \\
\hline $17-24$ & $71(27)$ & $2302(40)$ & Referent & - & - \\
\hline $25-34$ & $118(45)$ & $2109(36)$ & 1.81 & (1.34 to 2.45$)$ & 0.0001 \\
\hline $35+$ & $72(28)$ & $1390(24)$ & 1.68 & (1.20 to 2.35$)$ & 0.002 \\
\hline \multicolumn{6}{|l|}{ Marital status } \\
\hline Single & $159(61)$ & 2291 (39) & 2.37 & (1.84 to 3.05$)$ & $<0.0001$ \\
\hline Nonsingle & $102(39)$ & $3481(60)$ & Referent & - & - \\
\hline \multicolumn{6}{|l|}{ Education achieved } \\
\hline High school or less & $180(69)$ & $4105(71)$ & 0.86 & (0.66 to 1.12$)$ & 0.53 \\
\hline Some college or more & $80(31)$ & $1566(27)$ & Referent & - & - \\
\hline
\end{tabular}

n (\%) unless otherwise noted.

*Unless indicated otherwise characteristics shown are at time of study selection and for military personnel with 1 or more medical encounter; characteristics of female HIV-infected military personnel are in text; characteristics were unknown for the following: race- 5 cases and 135 controls; marital status-29 controls; education achieved-1 case and 130 controls. 
TABLE 2. Period of Observation, Frequency of Medical Encounters, and Service Related Assignments and Deployments Among 261 Male Active Duty Army and Air Force HIV-Infected and 5801 HIV-Uninfected Military Personnel

\begin{tabular}{|c|c|c|c|c|c|}
\hline Characteristic & Case & Control & Unadjusted Odds Ratio & $95 \% \mathrm{CL}$ & $P$ \\
\hline \multicolumn{6}{|c|}{ Service connection (yrs) } \\
\hline Overall* & $4.3,5.1(0.4-7.8)$ & $3.9,5.0(0.0-9.6)$ & - & - & $<0.0001$ \\
\hline More than 5.25 & $81(31)$ & $1427(25)$ & 1.96 & (1.36 to 2.85$)$ & 0.0004 \\
\hline $5.01-5.25$ & $69(26)$ & $1538(27)$ & 1.55 & (1.06 to 2.28$)$ & 0.02 \\
\hline $2.25-5.00$ & $66(25)$ & $1279(22)$ & 1.79 & (1.21 to 2.63$)$ & 0.003 \\
\hline Less than 2.25 & $45(17)$ & $1557(27)$ & Referent & - & - \\
\hline \multicolumn{6}{|l|}{ Follow-up (yrs) } \\
\hline Overall* & $2.4,2.5(0.1-6.2)$ & $2.2,2.2(0.0-4.7)$ & - & - & 0.009 \\
\hline Greater than 3.0 & $84(33)$ & $1467(26)$ & 1.43 & (1.04 to 1.98 ) & 0.03 \\
\hline $2.2-2.9$ & $48(19)$ & $1277(22)$ & 0.94 & (0.65 to 1.37$)$ & 0.75 \\
\hline $1.5-2.1$ & $48(19)$ & $1168(20)$ & 1.03 & (0.71 to 1.49$)$ & 0.88 \\
\hline Less than 1.5 & $72(29)$ & $1803(32)$ & Referent & - & - \\
\hline None & $9(3)$ & $86(2)$ & - & - & - \\
\hline \multicolumn{6}{|c|}{ Medical encounters (n) } \\
\hline Overall* & $25.5,20.0(1-126)$ & $20.4,15.0(1-324)$ & - & - & $<0.0001$ \\
\hline 28 or more & $89(34)$ & $1354(23)$ & 3.05 & (1.99 to 4.67 ) & $<0.0001$ \\
\hline $16-27$ & $69(26)$ & $1468(25)$ & 2.18 & (1.41 to 3.39 ) & 0.001 \\
\hline $8-15$ & $74(28)$ & $1632(28)$ & 2.11 & (1.36 to 3.26$)$ & 0.001 \\
\hline 7 or less & $29(11)$ & $1347(23)$ & Referent & - & - \\
\hline \multicolumn{6}{|c|}{ Permanent changes of station, total (n) } \\
\hline Overall* & $3.0,3.0(0-8)$ & $2.7,3.0(0-9)$ & - & - & 0.002 \\
\hline 3 or more & $164(63)$ & $3273(56)$ & 1.31 & (1.01 to 1.69 ) & 0.04 \\
\hline 2 or less & 97 (37) & $2528(44)$ & Referent & - & - \\
\hline \multicolumn{6}{|c|}{ Deployments, total (n) } \\
\hline Overall* & $0.3,0.0(0-4)$ & $0.3,0.0(0-7)$ & - & - & 0.03 \\
\hline 1 or more & $54(21)$ & $1530(26)$ & 0.73 & (0.54 to 0.99$)$ & 0.05 \\
\hline None & 207 (79) & $4271(74)$ & Referent & - & - \\
\hline \multicolumn{6}{|c|}{ Deployment duration, total (months) } \\
\hline Overall* & $4.3,3.6(0-18)$ & $5.5,5.0(0-40)$ & - & - & 0.06 \\
\hline 5 or more & $19(7)$ & $761(13)$ & 0.42 & (0.16 to 1.08$)$ & 0.01 \\
\hline $1-4$ & $27(10)$ & $642(11)$ & 0.71 & (0.28 to 1.76$)$ & 0.47 \\
\hline None & $215(82)$ & $4398(76)$ & Referent & - & - \\
\hline \multicolumn{6}{|c|}{ Deployment within the year before the index date } \\
\hline Yes & $25(10)$ & $1053(18)$ & 0.48 & (0.31 to 0.72$)$ & 0.0005 \\
\hline No & $236(90)$ & $4748(82)$ & Referent & - & - \\
\hline
\end{tabular}

Only $13(5 \%)$ cases in the study were female. At the time of HIV diagnosis all 13 were aged 21-42 years (mean, 28.9), in the Army and of enlisted pay grade, 7 were married, separated or divorced, 10 had a high school diploma or less, and 9 were of black racial origin. By comparison, $404 \mathrm{HIV}-$ uninfected control females in the study were aged 18-49 years (mean, 27.1), 212 (52\%) were in the Army, 339 (84\%) were enlisted, 220 (54\%) were married, separated, or divorced, 256 (63\%) had a high school diploma or less, and 205 (51\%) were of white race. Black race was associated with HIV infection $(\mathrm{OR}=5.00,95 \% \mathrm{CL}=1.33$ to 18.77$)$.

\section{Before HIV Diagnosis}

Overall, cases sought care more often (mean, 26.6 visits) than controls (mean, 21.3; $P<0.05$ ). Males with 2.25 or more years of service connection had higher odds of HIV infection
$(\mathrm{ORs}=1.55-1.96)$ compared with those with less than 2 years $(P \leq 0.05$, Table 2$)$. Males with 8 or more total medical encounters had 2-fold to 3-fold greater odds of HIV infection compared with male military personnel with 7 or fewer encounters $(\mathrm{ORs}=2.11-3.05$, Table 2$)$. Female cases than controls had longer service connection (mean years, 3.8 versus 3.5 ) and cases had more medical visits (mean, 49.5 versus $34.9 ; P>0.05)$. In the 4 years preceding HIV diagnosis, female cases contributed only 382 codes $(7 \%)$ to disease categories, of which none were associated with HIV infection ( $P \geq 0.05$, data not shown). Therefore, female military personnel were excluded from further evaluation in the study.

Overall, a higher proportion of cases than controls were diagnosed with incident conditions in 11 disease groups before HIV diagnosis: blood and blood-forming organs; circulatory system; endocrine, nutritional, metabolic, and immunity; 
digestive system; genitourinary system; infectious and parasitic diseases; mental disorders; respiratory system; skin and subcutaneous tissue; symptoms, signs, and ill-defined conditions; and $\mathrm{V}$ codes $(\mathrm{ORs}=1.28-5.22, P<0.05$, data not shown). All MDC were associated significantly with recent HIV seroconversion in both the 2-year and 4-year periods before HIV diagnosis after adjustment for age, race and years of service connection (adjusted odds ratio $[\mathrm{AOR}]=1.65-3.89$, $P<0.05$, Table 3).

In the final multivariate model including only male military personnel, 7 characteristics were associated the most with HIV infection (Table 4): single marital status (AOR = 14.37); having any clinical indicator or symptom within 4 years of HIV diagnosis $(\mathrm{AOR}=6.22)$; black race $(\mathrm{AOR}=$ 5.88); having any other clinical syndrome within 2 years of HIV diagnosis $(\mathrm{AOR}=3.31)$; any mental disorder within 4 years of HIV diagnosis (AOR = 3.04); longer service connection $(\mathrm{AOR}=1.69)$; and increasing age $(\mathrm{AOR}=1.12)$.

\section{After HIV Diagnosis}

Overall cases sought more care after diagnosis (mean visits, 48.9 versus 19.4) especially in the first year after diagnosis $(P<0.05)$. Higher overall health care seeking remained significant among cases after removing encounters where the primary diagnosis was HIV (mean, 35.7 visits, $P<0.05$ ).

The odds of STI diagnosis was higher among male cases than controls (cases 88 of 261 [34\%], controls 617 of 5801 $[11 \%] ; \mathrm{OR}=4.27,95 \% \mathrm{CL}=3.26$ to 5.60$)$. After stratification for pre-HIV history of STI, the odds of a STI post-HIV diagnosis remained higher among cases; (ORs: 3.14-4.15, Table 5; odds ratio, Mantel Haenszel $\left[\mathrm{OR}_{\mathrm{M}-\mathrm{H}}\right]=4.10,95 \% \mathrm{CL}=3.12$ to 5.40 ). The earliest STI was diagnosed between 0 and 42 months after HIV diagnosis (median, 8.2, IQR, 3.4-21.9). The odds of a mental disorder after HIV diagnosis was higher among male cases than controls (cases, 98 of 261 [37\%]; controls, 594 of 5801 $(10 \%) ; \mathrm{OR}=5.27,95 \% \mathrm{CL}=4.01$ to 6.92$)$. After stratification for pre-HIV history of mental disorder, the odds of a mental disorder post-HIV diagnosis remained higher among cases (ORs $=$ 4.42-5.14, Table 5; $\mathrm{OR}_{\mathrm{M}-\mathrm{H}}=4.98,95 \% \mathrm{CL}=3.77$ to 6.58 ).

Forty-seven (18\%) cases were hospitalized at least once after HIV diagnosis. Hospitalized cases had a higher number of visits before HIV diagnosis than non-hospitalized cases (mean, 34.5 versus $23.5 ; P=0.001$ ). More than $75 \%$ of primary diagnoses belonged to 4 disease groups: mental disorders, infectious diseases, digestive diseases, and respiratory diseases (see Appendix 2, Supplemental Digital Content 2, http://links.lww.com/QAI/A130). More than half of first hospitalizations (64\%) occurred within the first year after diagnosis (mean 11.6 months, median 5.8 months). Eighty-one percent of infectious disease admissions and 71\% of mental health hospitalizations occurred within the first year of diagnosis (mean months, 8.6 and 8.8, median months, 3.0 and 5.1 , respectively). The top 3 diagnoses in the mental disorders category were due to depression.

\section{DISCUSSION}

Our primary goal was to compare medical diagnoses among HIV-infected and uninfected military personnel and to identify conditions that may aid in earlier diagnosis of HIV. Although all medical diagnosis clusters were associated significantly with recent HIV diagnosis, in multivariate analysis 3 clusters (clinical indicators or symptoms suggestive of an acute retroviral syndrome, mental disorders, and other non-indicator clinical syndromes up to 2 years before HIV diagnosis) and 4 nonclinical characteristics (single marital status, black race, higher age, and longer service connection) were associated with recent diagnosis. HIV-infected military personnel had 3-fold to 6-fold greater odds than uninfected personnel of having clinical indicators or symptoms, mental disorders, and other clinical syndromes preceding HIV diagnosis. This suggests that increased attention to clinical factors and mental disorders may aid current HIV screening efforts leading to earlier diagnosis. It may also provide a window of opportunity for targeted prevention messages. Furthermore, although the US military HIV prevalence is lower than the CDC guideline threshold of $>0.1 \%$ for opt-out screening in health care settings, our data and reports of increasing HIV incidence among US Army military personnel since 2004 suggest that targeted HIV testing within the force testing interval may be indicated for males seeking care for clinical symptoms or mental health complaints, even in this highly HIV screened population. ${ }^{14,15,34}$

Earlier detection of HIV infection may curtail risk behaviors associated with HIV transmission through counseling. Some cohort studies have shown that an awareness of HIV infection decreased unprotected sex, other risk behaviors, and STIs compared with those with a negative HIV test or those not aware of their HIV infection. ${ }^{35}$ HIV-infected military personnel are counseled against unprotected consensual sex and are required to notify sexual partners of their infection status. $^{21,36}$ However, HIV-infected Soldiers and Airmen in this study continued to have higher odds of STIs after HIV diagnosis than uninfected military personnel. Additionally, having a history of STI before HIV diagnosis was associated with STIs post-HIV diagnosis. Given the approximately 9-month median time frame to the earliest STI diagnosis after $\mathrm{HIV}$ infection it is likely these diagnoses were not due mainly to co-infections at time of HIV diagnosis. Although increased monitoring may have impacted this result, it suggests opportunities for antecedent prevention messages.

Eighteen percent of male HIV-infected military personnel had at least 1 hospitalization. This is lower than other studies in the US that evaluated hospitalizations in the posthighly active antiretroviral therapy (HAART) era. Utilization of inpatient services in these studies varied from $21 \%$ to $34 \% .{ }^{37-39}$ Although the racial makeup of hospitalized cases in our study was similar to these studies, our cases were younger (mean, 29.6 years) which may explain our lower rate. Older age was associated with higher number of hospitalizations in one study which followed a US military cohort of HIVinfected individuals. ${ }^{39}$ Additionally, interval HIV-screening promotes earlier diagnosis as evidenced by high CD4 cell counts at diagnosis. ${ }^{40}$

Similar to studies in both civilian and military populations, infectious diseases and mental disorders were the primary reasons for hospitalization. In these studies, hospitalization occurred due to a variety of AIDS-defining illness 
TABLE 3. Occurrence of Medical Diagnoses in 2 Periods Before HIV Diagnosis or Study Selection Among 261 Male Active Duty Army and Air Force HIV-Infected and 5801 HIV 1-Uninfected Military Personnel

\begin{tabular}{|c|c|c|c|c|c|c|c|c|}
\hline \multirow[b]{2}{*}{$\begin{array}{l}\text { Medical Diagnosis } \\
\text { Cluster }\end{array}$} & \multicolumn{4}{|c|}{ In up to 2 Years Before HIV Diagnosis } & \multicolumn{4}{|c|}{ In up to 4 Years Before HIV Diagnosis } \\
\hline & Case & Control & $\begin{array}{l}\text { Unadjusted Odds } \\
\text { Ratio } \dagger,(95 \% \text { CL })\end{array}$ & $\begin{array}{c}\text { Adjusted Odds } \\
\text { Ratio } \%,(95 \% \text { CL) }\end{array}$ & Case & Control & $\begin{array}{l}\text { Unadjusted Odds } \\
\text { Ratio } \dagger,(95 \% \text { CL })\end{array}$ & $\begin{array}{c}\text { Adjusted Odds } \\
\text { Ratio } \%,(95 \% \text { CL) }\end{array}$ \\
\hline Any STI§ & $34(13)$ & $309(5)$ & 2.66 (1.82 to 3.89$)$ & 1.67 (1.09 to 2.57$)$ & $46(18)$ & $442(8)$ & 2.59 (1.86 to 3.62$)$ & $1.72(1.19$ to 2.49$)$ \\
\hline $\begin{array}{l}\text { Urethral discharge or } \\
\text { urethritis or } \\
\text { venereal disease or } \\
\text { orchitis and } \\
\text { epididymitis }\end{array}$ & $21(8)$ & $195(3)$ & - & - & $28(11)$ & $276(5)$ & - & \\
\hline Other $\|$ & $7(3)$ & $172(3)$ & - & - & $13(5)$ & $275(5)$ & - & - \\
\hline Chlamydia & $8(3)$ & $53(1)$ & - & - & $12(5)$ & $81(1)$ & - & - \\
\hline Syphilis & $2(1)$ & $4(0)$ & - & - & $3(1)$ & $10(0)$ & - & - \\
\hline Genital herpes & $3(1)$ & $32(1)$ & - & - & $4(2)$ & $50(1)$ & - & - \\
\hline Condyloma acuminatum & $3(1)$ & $20(0)$ & - & - & $4(2)$ & $33(1)$ & - & - \\
\hline Herpes simplex & $0(0)$ & $0(0)$ & - & - & $0(0)$ & $1(0)$ & - & - \\
\hline Hepatitis B virus & $0(0)$ & $2(0)$ & - & - & $2(1)$ & $5(0)$ & - & - \\
\hline Gonorrhoea & $1(0)$ & $31(1)$ & - & - & $5(2)$ & $40(1)$ & - & - \\
\hline $\begin{array}{l}\text { Any clinical indicator }(\mathrm{CI}) \text { or } \\
\text { symptom }(\mathrm{Sx}) \boldsymbol{9}\end{array}$ & $148(57)$ & $1755(30)$ & $3.02(2.35$ to 3.88$)$ & 2.67 (2.02 to 3.52$)$ & $193(74)$ & $2447(42)$ & $3.89(2.94$ to 5.15$)$ & $3.30(2.42$ to 4.49$)$ \\
\hline Pharyngitis & $77(30)$ & $664(11)$ & - & - & $112(43)$ & $1022(18)$ & - & - \\
\hline Headache & $27(10)$ & $310(5)$ & - & - & $43(16)$ & $470(8)$ & - & - \\
\hline Rash & $25(10)$ & $242(4)$ & - & - & $42(16)$ & $426(7)$ & - & - \\
\hline Abdominal pain & $24(9)$ & $317(5)$ & - & - & $42(16)$ & $473(8)$ & - & - \\
\hline Diarrhea & $21(8)$ & $122(2)$ & - & - & $24(9)$ & $185(3)$ & - & - \\
\hline Nausea and/or vomiting & $18(7)$ & $159(3)$ & - & - & $24(9)$ & $240(4)$ & - & - \\
\hline Lymphadenopathy & $19(7)$ & $103(2)$ & - & - & $23(9)$ & $158(3)$ & - & - \\
\hline Malaise & $16(6)$ & $169(3)$ & - & - & $25(10)$ & $304(5)$ & - & - \\
\hline Migraine & $13(5)$ & $65(1)$ & - & - & $20(8)$ & $98(2)$ & - & - \\
\hline Fever & $14(5)$ & $88(2)$ & - & - & $19(7)$ & $129(2)$ & - & - \\
\hline Blood disorders & $10(4)$ & $36(1)$ & - & - & $15(6)$ & $44(1)$ & - & - \\
\hline Anal sores & $6(2)$ & $28(0)$ & - & - & $9(3)$ & $35(1)$ & - & - \\
\hline Pneumonia & $5(2)$ & $84(1)$ & - & - & $8(3)$ & $138(2)$ & - & - \\
\hline Herpes zoster & $2(1)$ & $12(0)$ & - & - & $2(1)$ & $19(0)$ & - & - \\
\hline Weight loss & $3(1)$ & $8(0)$ & - & - & $4(2)$ & $12(0)$ & - & - \\
\hline Peripheral neuropathy & $2(1)$ & $31(1)$ & - & - & $7(3)$ & $48(1)$ & - & - \\
\hline Any mental disorder $(\mathrm{MH})^{* *}$ & $29(11)$ & $297(5)$ & $2.32(1.55$ to 3.47$)$ & $2.53(1.60$ to 4.01$)$ & 37 (14) & $406(7)$ & $2.20(1.53$ to 3.15$)$ & 2.27 (1.51 to 3.40$)$ \\
\hline Adjustment disorders & $14(5)$ & $158(3)$ & - & - & $19(7)$ & $223(4)$ & - & - \\
\hline Depression & $12(5)$ & $139(2)$ & - & - & $16(6)$ & $183(3)$ & - & - \\
\hline Stress, anxiety & $12(5)$ & $92(2)$ & - & - & $18(7)$ & $119(2)$ & - & - \\
\hline Substance use & $5(2)$ & $161(3)$ & - & - & $8(3)$ & $207(4)$ & - & - \\
\hline Any other clinical syndromes (CS) $\dagger \dagger$ & $126(48)$ & $2051(35)$ & $1.71(1.33$ to 2.19$)$ & 2.22 (1.68 to 2.93$)$ & $163(62)$ & $2916(50)$ & $1.65(1.27$ to 2.13$)$ & 1.91 (1.43 to 2.54$)$ \\
\hline Upper respiratory infection & $87(33)$ & $1583(27)$ & - & - & $121(46)$ & $2254(39)$ & - & - \\
\hline Unspecified viral infection & $55(21)$ & $454(8)$ & - & - & $84(32)$ & $857(15)$ & - & - \\
\hline Gastroenteritis/colitis & $38(15)$ & $434(7)$ & - & - & $57(22)$ & $729(13)$ & - & - \\
\hline Mononucleosis & $4(2)$ & $9(0)$ & - & - & $4(2)$ & $19(0)$ & - & - \\
\hline Any STI, CI, or Sx & $41(16)$ & $354(6)$ & 2.89 (2.02 to 4.07$)$ & $1.96(1.32$ to 2.89$)$ & $52(20)$ & $484(8)$ & $2.73(1.99$ to 3.76$)$ & $1.91(1.34$ to 2.71$)$ \\
\hline Any STI or MH & $57(22)$ & $585(10)$ & 2.49 (1.84 to 3.38$)$ & 1.93 (1.36 to 2.72 ) & $74(28)$ & $805(10)$ & $2.46(1.86$ to 3.25$)$ & 1.93 (1.42 to 2.63$)$ \\
\hline Any STI, CI, Sx, or MH & $62(24)$ & $624(11)$ & 2.59 (1.92 to 3.48$)$ & 2.04 (1.46 to 2.85$)$ & $78(30)$ & $841(15)$ & $2.51(1.91$ to 3.31$)$ & 2.00 (1.48 to 2.72$)$ \\
\hline Any STI, CI, Sx, MH, CS & $196(75)$ & $3106(54)$ & $2.62(1.97$ to 3.48$)$ & $2.59(1.90$ to 3.53$)$ & $230(88)$ & $3959(68)$ & $3.45(2.36$ to 5.04$)$ & $3.21(2.13$ to 4.86$)$ \\
\hline $\begin{array}{l}\text { n (\%) unless otherwise noted. 2-si } \\
\text { *For cases with last HIV-negative } \\
\text { †Unadjusted odds ratio, referent g } \\
\text { †Age and race adjusted odds ratio, } \\
\text { Airmen. } \\
\text { §Any of the following were consid } \\
\text { acuminatum, Chlamydia. } \\
\| \text { "Other" included cytomegalic ind } \\
\text { } \text { Indicators and symptoms reporte } \\
\text { **Substance use was excluded sin } \\
\dagger † \text { Diagnoses that commonly occu }\end{array}$ & $\begin{array}{l}\text { only militar } \\
\text { dered: vene } \\
\text { clusion in dise } \\
\text { ce it was n }\end{array}$ & $\begin{array}{l}\text { se without } \\
\text { ry personnel } \\
\text { real disease, } \\
\text { ease, viral w } \\
\text { ure and that } \\
\text { lot associate }\end{array}$ & $\begin{array}{l}\text { ratios were }<0.001 \text {. } \\
\text { medical encounters tha } \\
\text { vidence of condition. } \\
\text { with more than } 2 \text { years o } \\
\text { urethral discharge, ureth } \\
\text { arts, Trichomonas, Mollu } \\
\text { were diagnosed among } \\
\text { with HIV infection. }\end{array}$ & $\begin{array}{l}\text { It occurred between the } \\
\text { f service connection incl } \\
\text { ritis, vaginitis, orchitis a } \\
\text { uscum contagiosum. } \\
\text { HIV-infected military pe }\end{array}$ & $\begin{array}{l}\text { last HIV ne } \\
\text { uded ( } 224 \mathrm{c} \\
\text { and epididy } \\
\text { rsonnel. }\end{array}$ & cases, 4384 & hepatitis B virus, geni & $\begin{array}{l}\text { considered. } \\
\text { al herpes, } 116 \text { Soldiers and } \\
\text { aloma }\end{array}$ \\
\hline
\end{tabular}


TABLE 4. Characteristics Retained in a Multivariate Model That Were Most Associated With HIV Infection*

\begin{tabular}{|c|c|c|c|c|c|}
\hline Characteristic & $\boldsymbol{\beta}$ & Standard Error & Odds Ratio & $95 \% \mathrm{CL}$ & $P$ \\
\hline \multicolumn{6}{|l|}{ Race } \\
\hline Black & 1.77 & 0.3289 & 5.88 & (3.09 to 11.21 ) & $<0.0001$ \\
\hline Nonblack & - & - & 1.00 & - & - \\
\hline Age (per year increase) & 0.11 & 0.0274 & 1.12 & (1.06 to 1.18$)$ & $<0.0001$ \\
\hline \multicolumn{6}{|l|}{ Marital status } \\
\hline Single & 2.66 & 0.3941 & 14.37 & (6.64 to 31.13 ) & $<0.0001$ \\
\hline Nonsingle & - & - & 1.00 & - & - \\
\hline Service connection (per year increase) & 0.52 & 0.1864 & 1.69 & (1.17 to 2.43$)$ & 0.005 \\
\hline Presence of any clinical indicator or symptom up to 4 years before HIV diagnosis & 1.83 & 0.4122 & 6.22 & (2.77 to 13.96$)$ & $<0.0001$ \\
\hline Presence of any mental disorder up to 4 years before HIV diagnosis & 1.11 & 0.4480 & 3.04 & (1.26 to 7.32$)$ & 0.013 \\
\hline Presence of any other clinical syndromes up to 2 years before HIV diagnosis & 1.20 & 0.3376 & 3.31 & (1.71 to 6.41$)$ & 0.0004 \\
\hline Intercept & -13.14 & 0.34 & - & - & - \\
\hline
\end{tabular}

*The Hosmer-Lemeshow chi-square statistic of 6.73 , with 8 degrees of freedom, and a $P$-value of 0.57 indicated the null hypothesis that the data fit the final model was accepted.

and infections such as pneumonia or methicillin-resistant Staphylococcus aureus, gastrointestinal diseases such as pancreatitis and mental disorders, and primarily major depressive disorder or substance use-related diagnoses. ${ }^{37,39}$ HIV viral load, CD4 cell counts, and use of HAART were associated with the type of hospitalization and rate of hospitalization. The infectious diseases that made up the primary reasons for hospitalization in our study were nonAIDS-related and suggest that HIV-infected Soldiers and Airmen were not late presenters for HIV medical care. Outpatient medical utilization for ICD9 primary diagnoses other than HIV was significantly greater postdiagnosis. A similar finding was apparent in a recent case-control study of mild asthma among Navy recruits. ${ }^{41}$ Implications for resourcing treatment facilities and costs merit further investigation.

We found single marital status, black race, male gender, older age, and longer service connection were associated with HIV seroconversion. These findings are consistent with trends of the HIV epidemic in the US Army since the mid-1980s. ${ }^{42,43}$ Although we did not evaluate the effect of length of active duty service history on HIV acquisition, time in service may be associated with HIV seroconversion. Infected military

TABLE 5. Sexually Transmitted Infections and Mental Disorders by HIV Infection Status in Up to 4 Years After HIV Diagnosis Among 261 Male Active Duty Army and Air Force HIV-Infected and 5801 HIV-Uninfected Military Personnel

\begin{tabular}{|c|c|c|c|c|c|c|c|c|}
\hline & Case & Control & Odds Ratio* & $(95 \% \mathrm{CL})$ & Case & Control & Odds Ratio* & $(95 \% \mathrm{CL})$ \\
\hline & \multicolumn{4}{|c|}{ Preindex history of STI $($ case $=46$, control $=442)$} & \multicolumn{4}{|c|}{ No preindex history of STI $($ case $=215$, control $=5359)$} \\
\hline Any postdiagnosis $\mathrm{STI} \uparrow$ & $22(48)$ & $100(23)$ & 3.14 & (1.69 to 5.83$)$ & $66(31)$ & $517(10)$ & 4.15 & (3.06 to 5.62$)$ \\
\hline Herpes simplex & $0(0)$ & $0(0)$ & - & - & $2(1)$ & $3(0)$ & - & - \\
\hline Other $\dagger$ & $10(22)$ & $28(6)$ & - & - & $19(9)$ & $238(4)$ & - & - \\
\hline $\begin{array}{l}\text { Urethral discharge or urethritis } \\
\text { or venereal disease or } \\
\text { orchitis and epididymitis }\end{array}$ & $4(9)$ & $52(12)$ & - & - & $22(10)$ & $194(4)$ & - & - \\
\hline Syphilis & $5(11)$ & $3(1)$ & - & - & $16(7)$ & $0(0)$ & - & - \\
\hline Hepatitis B virus & $4(9)$ & $0(0)$ & - & - & $4(2)$ & $2(0)$ & - & - \\
\hline Genital herpes & $2(4)$ & $18(4)$ & - & - & $11(5)$ & $50(1)$ & - & - \\
\hline Gonorrhoea & $0(0)$ & $8(2)$ & - & - & $5(2)$ & $18(0)$ & - & - \\
\hline Condyloma acuminatum & $9(20)$ & $7(2)$ & - & - & $12(6)$ & $34(1)$ & - & - \\
\hline \multirow[t]{2}{*}{ Chlamydia } & $2(4)$ & $11(2)$ & - & - & $7(3)$ & $42(1)$ & - & - \\
\hline & \multicolumn{4}{|c|}{$\begin{array}{l}\text { Preindex history of mental disorder } \\
\quad(\text { case }=37, \text { control }=406)\end{array}$} & \multicolumn{4}{|c|}{$\begin{array}{l}\text { No preindex history of mental } \\
\text { disorder }(\text { case }=224, \text { control }=5395)\end{array}$} \\
\hline Any postdiagnosis mental disorder & $25(68)$ & $130(32)$ & 4.42 & (2.16 to 9.08$)$ & $73(33)$ & $464(9)$ & 5.14 & (3.83 to 6.90$)$ \\
\hline Adjustment disorders & $17(46)$ & $64(16)$ & - & - & $54(24)$ & $267(5)$ & - & - \\
\hline Depression & $18(49)$ & $86(21)$ & - & - & $37(17)$ & $210(4)$ & - & - \\
\hline Stress, anxiety & $12(32)$ & $41(10)$ & - & - & $19(8)$ & $184(3)$ & - & - \\
\hline Substance use & $6(16)$ & $33(8)$ & - & - & $10(4)$ & $210(4)$ & - & - \\
\hline
\end{tabular}

n (\%) unless otherwise indicated.

*Unadjusted odds ratio, referent group is those without evidence of condition; any of the following were considered: venereal disease, urethral discharge, urethritis, vaginitis, orchitis and epididymitis, syphilis, HBV, genital herpes, Condyloma acuminatum, Chlamydia, gonorrhoea.

$\dagger$ †Other" included cytomegalic inclusion disease, viral warts, Trichomonas, Molluscum contagiosum. 
personnel had longer service connection in our study and higher HIV seroconversions have been reported among those with 3 or more years of service. ${ }^{19}$

There are limitations to our study. We were unable to reliably assess women cases, Hispanic race, or ethnicity as our population has very few women cases, and race or ethnicity were aggregated for fewer population numbers. We evaluated archived records of medical encounters with commonly used nosology. The ICD-9-CM codes were not validated with medical chart reviews and therefore may not reflect actual diagnoses or capture encounters in locations where diagnostic coding does not occur. The association between both indicator and nonindicator MDC and HIV infection is limited by the absence of laboratory confirmation and potential lack of specificity of these diagnoses as representing clinically apparent acute retroviral illnesses. However, this limitation is mitigated by laboratory-confirmed HIV infection that followed these events. It is possible that providers might have selectively coded HIV-related visits using non-specific diagnostic coding to maintain patient confidentiality with respect to HIV infection status. This possibility, and any potential impact, could not be evaluated.

In conclusion, HIV-infected Soldiers and Airmen frequently sought health care for symptoms suggestive of acute or early stage HIV infection and mental disorders in the 2-4 years preceding HIV diagnosis. Although validation of these findings is necessary in site-specific prospective studies which incorporate behavioral risk factors and cost-benefit analysis of point-of-care HIV testing, increased attention by health care providers to the mental health and care-seeking patterns in their military patients may increase earlier detection of HIV infection, reduce ongoing HIV transmission, and facilitate earlier access to antiretroviral therapy. STI rates increased after HIV diagnosis, which implies increased risk behavior or increased susceptibility. Further study is needed in this population to determine the impact of HIV infection on subsequent STI risk.

\section{REFERENCES}

1. Campsmith ML, Rhodes PH, Hall HI, et al. Undiagnosed HIV prevalence among adults and adolescents in the United States at the end of 2006. J Acquir Immune Defic Syndr. 2010;53:619-624.

2. Wawer MJ, Gray RH, Sewankambo NK, et al. Rates of HIV-1 transmission per coital act, by stage of HIV-1 infection, in Rakai, Uganda. J Infect Dis. 2005;191:1403-1409.

3. Quinn TC, Wawer MJ, Sewankambo N, et al. Viral load and heterosexual transmission of human immunodeficiency virus type 1. Rakai Project Study Group. N Engl J Med. 2000;342:921-929.

4. White DA, Warren OU, Scribner AN, et al. Missed opportunities for earlier HIV diagnosis in an emergency department despite an HIV screening program. AIDS Patient Care STDs. 2009;23:245-250.

5. Gandhi NR, Skanderson M, Gordon KS, et al. Delayed presentation for human immunodeficiency virus (HIV) care among veterans: a problem of access or screening? Medical Care. 2007;45:1105-1109.

6. Centers for Disease Control and Prevention. Missed opportunities for earlier diagnosis of HIV infection - South Carolina, 1997-2005. MMWR Morb Mortal Wkly Rep. 2006;55:1269-1272.

7. Klein D, Hurley LB, Merrill D, et al. Review of medical encounters in the 5 years before a diagnosis of HIV-1 infection: implications for early detection. J Acquir Immune Defic Syndr. 2003;32:143-152.

8. Pincus JM, Crosby SS, Losina E, et al. Acute human immunodeficiency virus infection in patients presenting to an urban urgent care center. Clin Infect Dis. 2003;37:1699-1704.
9. Sharghi N, Bosch RJ, Mayer K, et al. The development and utility of a clinical algorithm to predict early HIV-1 infection. J Acquir Immune Defic Syndr. 2005;40:472-478.

10. Herbold JR. AIDS policy development within the Department of Defense. Military Med. 1986;151:623-627.

11. Tramont EC, Redfield R, Burke D, et al. HTLV-III/LAV infections in the military. Military Med. 1987;152:105-106.

12. Department of Defense. Armed Forces Epidemiological Board. Testing Interval for Human Immunodeficiency Virus (HIV-1) Infection in Military Personnel-2003-2005. December 24, 2003.

13. Hall HI, Song R, Rhodes P, et al. Estimation of HIV incidence in the United States. JAMA. 2008;300:520-529.

14. Department of Defense, Defense Health Board (formerly: Armed Forces Epidemiological Board). Memorandum for Assistant Secretary of Defense (Health Affairs), Subject: Testing Interval for Human Immunodeficiency Virus (HIV-1) Infection in Military Personnel- 2003-2005. December 24, 2003. Available at: http://www.health.mil/dhb/default.cfm. Accessed January 28, 2011.

15. Department of Defense. Armed Forces Health Surveillance Center Updates: Routine screening for antibodies to HIV-1, civilian applicants for U.S. military service and U.S. Armed Forces, active and reserve components. Med Surveill Monthly Rep. 2009;16:2-11.

16. Singer DE, Bautista CT, O'Connell RJ, et al. HIV infection among U.S. Army and Air Force military personnel: sociodemographic and genotyping analysis. AIDS Res Hum Retroviruses. 2010;26:889-894.

17. Bautista CT, Singer DE, O'Connell RJ, et al. Herpes simplex virus type 2 and HIV infection among US military personnel: implications for health prevention programmes. Int J STD AIDS. 2009;20:634-637.

18. Department of Defense. Armed Forces Health Surveillance Center. Force strength, US Army, December 1999. Med Surveill Monthly Rep. 2000;6:22-23.

19. Renzullo PO, Sateren WB, Garner RP, et al. HIV-1 seroconversion in United States Army active duty personnel, 1985-1999. AIDS. 2001;15:1569-1574.

20. Rubertone MV, Brundage JF. The Defense Medical Surveillance System and the Department of Defense serum repository: glimpses of the future of public health surveillance. Am J Public health. 2002;92:1900-1904.

21. Department of the Air Force. Air Force Instruction: Human immunodeficiency virus program. AFI 48-135. August 1, 2000. Updated version available at: http://www.af.mil/shared/media/epubs/AFI48-135.pdf. Accessed January 28, 2011.

22. Bernard S, ed. 1997 ICD-9-CM: International Classification of Diseases: 9th Revision. Clinical modification. 5th ed. Salt Lake City, UT: Medicode Inc; 1996.

23. Bollinger RC, Brookmeyer RS, Mehendale SM, et al. Risk factors and clinical presentation of acute primary HIV infection in India. JAMA. 1997; 278:2085-2089.

24. Burchell AN, Calzavara L, Ramuscak N, et al. Symptomatic primary HIV infection or risk experiences? Circumstances surrounding HIV testing and diagnosis among recent seroconverters. Int J STD AIDS. 2003;14:601-608.

25. Celum CL, Buchbinder SP, Donnell D, et al. Early human immunodeficiency virus (HIV) infection in the HIV Network for Prevention Trials Vaccine Preparedness Cohort: risk behaviors, symptoms, and early plasma and genital tract virus load. $J$ Infect Dis. 2001;183:23-35.

26. Coco A, Kleinhans E. Prevalence of primary HIV infection in symptomatic ambulatory patients. Ann Fam Med. 2005;3:400-404.

27. Daar ES, Little S, Pitt J, et al. Diagnosis of primary HIV-1 infection. Los Angeles County Primary HIV Infection Recruitment Network. Ann Int Med. 2001;134:25-29.

28. Freedberg KA, Samet JH. Think HIV: why physicians should lower their threshold for HIV testing. Arch Intern Med. 1999;159:1994-2000.

29. Hecht FM, Busch MP, Rawal B, et al. Use of laboratory tests and clinical symptoms for identification of primary HIV infection. AIDS. 2002;16: $1119-1129$.

30. Kassutto S, Rosenberg ES. Primary HIV type 1 infection. Clin Infect Dis. 2004;38:1447-1453

31. Kelley CF, Barbour JD, Hecht FM. The relation between symptoms, viral load, and viral load set point in primary HIV infection. $J$ Acquir Immune Defic Syndr. 2007;45:445-448.

32. Schacker TW, Hughes JP, Shea T, et al. Biological and virologic characteristics of primary HIV infection. Ann Intern Med. 1998;128: 613-620.

33. Zetola NM, Pilcher CD. Diagnosis and management of acute HIV infection. Infect Dis Clin North Am. 2007;21:19-48. vii. 
34. Branson BM, Handsfield HH, Lampe MA, et al. Revised recommendations for HIV testing of adults, adolescents, and pregnant women in health-care settings. MMWR Recomm Rep. 2006;55(RR-14):1-17; quiz CE11-14.

35. Marks G, Crepaz N, Senterfitt JW, et al. Meta-analysis of high-risk sexual behavior in persons aware and unaware they are infected with HIV in the United States: implications for HIV prevention programs. J Acquir Immune Defic Syndr. 2005;39:446-453.

36. Department of the Army. Identification, surveillance, and administration of personnel infected with human immunodeficiency virus (HIV). Army Regulation 600-110. July 15, 2005. Available at: http://www.apd.army. mil/pdffiles/r600_110.pdf. Accessed January 28, 2011.

37. Betz ME, Gebo KA, Barber E, et al. Patterns of diagnoses in hospital admissions in a multistate cohort of HIV-positive adults in 2001. Med Care. 2005;43(9 suppl):III3-III14.

38. Fleishman JA, Gebo KA, Reilly ED, et al. Hospital and outpatient health services utilization among HIV-infected adults in care 2000-2002. Med Care. 2005;43(9 suppl):III40-III52.
39. Crum-Cianflone NF, Grandits G, Echols S, et al. Trends and causes of hospitalizations among HIV-infected persons during the late HAART era: what is the impact of CD4 counts and HAART use? $J$ Acquir Immune Defic Syndr. 2010;54:248-257.

40. Marconi VC, Grandits GA, Weintrob AC, et al. Outcomes of highly active antiretroviral therapy in the context of universal access to healthcare: the U.S. Military HIV Natural History Study. AIDS Res Ther. 2010;7:14

41. Millikan AM, Niebuhr DW, Brundage M, et al. Retention of mild asthmatics in the navy (REMAIN): a low-risk approach to giving mild asthmatics an opportunity for military service. Military Med. 2008;173: 381-387.

42. McNeil JG, Brundage JF, Gardner LI, et al. Trends of HIV seroconversion among young adults in the US Army, 1985 to 1989. US Army Retrovirus Research Group. JAMA. 1991;265:1709-1714.

43. Kelley PW, Miller RN, Pomerantz R, et al. Human immunodeficiency virus seropositivity among members of the active duty US Army 198589. Am J Public Health. 1990;80:405-410. 